\title{
The Naturalness of Translation in Translating Short Story Entitled "Drupadi" from Indonesian into English
}

\author{
N. L. P. V. Dewi ${ }^{1}$, A. Mardjohan ${ }^{2}$, M. H. Santosa ${ }^{3}$. \\ Jurusan Pendidikan Bahasa Inggris \\ Universitas Pendidikan Ganesha \\ Singaraja, Indonesia \\ e-mail: \{vitadewi119@yahoo.com, asrilmardjohan@gmail.com, \\ info@mhsantosa.com\}@undiksha.ac.id
}

\begin{abstract}
This study aimed at analyzing the naturalness of translation and finding the percentage of the naturalness of translation in translating short story entitled "Drupadi" from Indonesian into English. The subjects of this study were two native speakers which are come from the native area. Meanwhile, the object of this study was a short story entitled "Drupadi" especially the sentences in both Indonesian and English version. In this study, the researcher used Larson's theory as the reference of the study in order to analyze the naturalness of translation in short story entitled "Drupadi" from Indonesian into English. The data were obtained by two methods of data collection, namely checklist and interview. The total of the data in this study was 131 sentences and it was analyzed descriptively.

The result of this study showed that, $0 \%$ of the data is considered to fall into "unnatural" level, $2.29 \%$ are considered to fall into "less natural" level, $13.74 \%$ of the data belong to the "natural" level, and $83.97 \%$ of the data is classified as "highly natural". Based on the result, it can be concluded that the short story entitled "Drupadi" which has been translated by Tom Hunter from Indonesian into English was in "highly natural" level and it can be used as teaching material for the teacher who teaches language, especially translation.
\end{abstract}

Key words: translation, short story, the naturalness

\begin{abstract}
ABSTRAK
Penelitian ini bertujuan untuk menganalisis keberterimaan terjemahaan dan menemukan persetanse dari keberterimaan terjemahaan tersebut dalam cerita pendek yang berjudul "Drupadi" yang diterjemahkan dari Bahasa Indonesia kedalam Bahasa Inggris. Subjek dalam penelitian ini adalah dua native speakers yang berasal dari native area. Sedangkan, objek dalam penelitian ini yaitu cerita pendek yang berjudul "Drupadi" khususnya kalimat-kalimat yang terdapat dalam kedua versi cerita.Dalam penelitian ini, peneliti menggunakan teori Larson sebagai teori acuan penelitian untu menganalisis
\end{abstract}


keberterimaan terjemahaan cerita pendek yang berjudul "Drupadi" dari Bahasa Indonesia kedalam Bahasa Inggris.Tterdapat dua cara yang dilakukan oleh peneliti untuk mengumpulkan data, yiatu dengan menggunakan checklist dan melakukan interview. Jumlah data yang digunakan dalam penelitian ini yaitu 131 kalimat dan data tersebut di analisis secara descriptif.

Hasil penelitian menunjukkan bahwa data yang tergolong dalam tingkat "unnatural" sebanyak 0\%, 2.29\% untuk data yang tergolong dalam tingkat "less natural", $13.74 \%$ untuk data yang tergolong dalam tingkat "natural", dan $83.97 \%$ untuk data yang tergolong ke dalam tingkat "highly natural". Berdasarkan hasil penelitian, dapat disimpulkan bahwa cerita pendek yang berjudul "Drupadi" yang diterjemahkan oleh Tom Hunter dari Bahasa Indonesia ke dalam Bahasa Inggris tergolong dalam tingkat "highly natural" dan cerita pendek tersebut dalam digunakan sebagai bahan ajar oleh guru yang mengajar bahasa, khususnya dalam bidang terjemahaan.

Kata kunci: terjemahaan, cerita pendek, keberterimaan

\section{INTRODUCTION}

One important function of language is as the tool of communication. Regarding that reason, all people in the world use language for interacting and communicating with others. Nowadays, diversity of language and development of science and technology lead people to be able to communicate in different languages. There are several languages that should be mastered by people in order to communicate with others who comes from different country, for example is English.

According to Putri (2014), English is an international language that is used as the language communication between all the nations and countries in the world. The ability to speak English is important to be mastered by people. It is because, through English, people can interact with the foreigner. Moreover, there are several occupations that related to English, such as a translator.

A translator is a person who translates the original language into the target language in order to make the foreigner easily to understand the information. Through a translator, people can get the accurate and clear information without having difficulties to understand the information that are given by foreigners.

Larson (1998) states that translation is the transferring process fromthe original message into the target language. He adds that translation is a process of translation which is not only in one sense, buthaving two or more meanings. There are several criteria of good translation based on the experts such as Larson (1998), Barnwell (1980, p. 115) and Nababan (2003, p. 86). From their explanations, it can be concluded that there are three most important qualities of a good translation, such as accuracy, clarity, and naturalness.

According to Larson (1198), a translation is basically a change of form. In translating a text, a translator must be careful because she/he has to translate the text accurately, naturally, and communicatively in order to make the readers easier to understand the text. Therefore, translating a text is obviously not a simple and easy work. In translating a text, a translator should understand the aspects related to the translation process 
of a text, so the meaning between SL and $\mathrm{TL}$ is equivalent and also it can be read naturally.

Besides accuracy and clarity, in translation, the naturalness is also important thing that must be considered by the translator. It is because, if the translator already translates the SL accurately and clearly but the sentence of the TL sounds awkward and unnatural, it will make the reader difficult to understand the information of the text. In that case, the translator should be able to choose the appropriate word which has the closest meaning with the original text.

There are several Indonesian texts and stories that are translated into English, such as short story. Based on the researcher observation, there are some short stories which are translated from Indonesian into English inaccurately and naturally. One of them is the short story entitled "Drupadi". "Drupadi" is one of the famous Balinese short stories which tell about karma and samsara. That story has been published by HiVOS-UWRF in Ubud Writers \& Readers Festival 2009 which held in Ubud, Bali, Indonesia.

The short story entitled "Drupadi" is written by Putu Fajar Arcana and it has been translated into English by Tom Hunter. Based on the researcher's observation, the researcher found that there are several mistakes that made by the translator in translating the short story entitled "Drupadi", such as there are some inappropriate words that are used by the translator in order to translate the SL. For example, on the page 62 , the sentence "Anehnya, pada setiap kelahiranku kembali aku bertemu dengan kakek" was translated into "And it's strange that everything I'm born again I always meet grandfather again." In this translation, the translator translates the word setiap into everything. The meaning of the TL of that sentence is not equivalent with SL. The translator should translate the word setiap into every time. It is because setiap refers to the time, therefore the appropriate word that should be used to translate it is every time.

Based on those phenomena, it is interesting to conduct a research on translation especially in analyzing the naturalness of translation. There are some researches that have been conducted especially on translation. As in Farahani and Ghasemi (2012). Their research was focused on the naturalness of translation especially in translating idioms and proverbs. Their research aimed to explore the strategies which were applied for translating idioms and proverbs in the corpus of the study from English to Persian and identify the most frequently strategies. The result of their research showed that the translator translated the idioms and proverbs in an idiomatic and natural way.

In this study, the researcher used a short story entitled "Drupadi" especially the sentences in both of Indonesian and English version as the object of the study. The researcher analyzes the naturalness of translation of the short story entitled "Drupadi" which has been translated into English by Tom Hunter deeply. In this study, the researcher used Larson's theory especially the naturalness of translation theory as the reference of the study. The researcher is also helped by two native speakers in collecting the data.

\section{METHODS}

This study was descriptive qualitative research. The data of this study was analyzed descriptively, in which the researcher only reported the naturalness of translation and the percentage of the naturalness of translation in translating a 
short story entitled "Drupadi" from Indonesian into Englsih.

The subjects of the study were two native speakers and two expert judges. Meanwhile, the object of this study was the short story entitled "Drupadi". The obtained data was come from the sentences of the short story entitled "Drupadi" in both Indonesian and English version.In this study, the researcher focused on the naturalness sentences in English version of the short story.

The native speakers that were chosen by the researcher must fulfill the following criteria, such as: (1) the native speakers have to masterEnglish, (2) the native speaker should be fluent in speaking
Bahasa, and (3) the native speakers are from the native areas (Australia, US, and UK). Meanwhile, the two expert judges that were chosen by the researcher must fulfil the following criteria, such as: (1) the expert judges should be qualified at least post graduated lecturer, and (2) the expert judges should be lecturers who teach language, especially translation.

There are several instruments that are used in this study in order to find the intended data, namely: researcher as the key instrument, checklist, and interview.

The criteria of the checklist that is used in this study is based on the Larson's theory especially the criteria of the naturalness of translation. The criteria of the naturtalness of translation can be seen on the Table 3.2.

\section{Table 3.2. The scale of the naturalness of translation in translating short story entitled "Drupadi"}

\begin{tabular}{|l|l|l|}
\hline Scale & \multicolumn{1}{|c|}{ Level } & \multicolumn{1}{c|}{ Criteria } \\
\hline 4 & Highly natural & $\begin{array}{l}\text { Make sense and read naturally (written in ordinary language, } \\
\text { common grammar, proper idioms and words) }\end{array}$ \\
\hline 3 & Natural & $\begin{array}{l}\text { Correct meaning, using appropriate idioms and words but } \\
\text { there are some error structures. }\end{array}$ \\
\hline 2 & Less natural & $\begin{array}{l}\text { Make sense with minimum unnatural words, grammar, phrase } \\
\text { and idiom. }\end{array}$ \\
\hline 1 & Unnatural & $\begin{array}{l}\text { Unnatural form, with awkward language, ungrammatical } \\
\text { structure and inappropriate word. }\end{array}$ \\
\hline
\end{tabular}

Adapted from: The quality of naturalness in translation (Larson, 1998, pp. 531-532)

\section{RESULTS}

\section{The naturalness of translation in translating a short story entitled "Drupadi"}

The result of the checklists shows that the short story entitled "Drupadi" that has been translated by Tom Hunter was in category "highly natural" with the percentage of $83.97 \%$. It could be concluded that the short story entitled "Drupadi" that has been translated into English by Tom Hunter is "highly natural" and it can be used as the reference of teaching material for teacher who teaches 
language especially translation. However, there were several error sentences that must be revised. The common errors that were found in translating short story entitled "Drupadi" from Indonesian into English were ungrammatically structures, mechanics error (punctuation, spelling, and repetition), the meaning from the SL was not equivalence with the $T L$, and the translator used inappropriate words in translating the TL.

The result of the data analysis of the naturalness of translation in translating short story entitled "Drupadi" from Indonesian into English can be discussed as following:

\subsection{Unnatural Level}

Unnatural data might be caused by the ungrammatical structures in translating the TL. The use of inappropriate word in translating the $\mathrm{TL}$, or the mechanics error in translating the $T L$ which made the sentences sounded unnatural and the meaning between the TL and SL were not equivalent. In this level, the data must cover 1.0-1.5 for the mean score. The result of the checklist analysis shows that the data which belong to this level is 0 $(0 \%)$. The example of the unnatural data can be seen on the Table 4.1.

Table 4.1. The short story entitled "Drupadi"

\begin{tabular}{|c|l|l|l|c|c|c|}
\hline No & \multicolumn{1}{|c|}{$\begin{array}{c}\text { Source Language } \\
\text { Indonesian Version) }\end{array}$} & \multicolumn{1}{|c|}{$\begin{array}{c}\text { Target Language } \\
\text { (English Version) }\end{array}$} & \multicolumn{3}{|c|}{ Score } \\
\cline { 2 - 6 } & $\begin{array}{l}\text { Untungnya, lelaki yang } \\
\text { berkumis tebal ini pandai } \\
\text { memasak. }\end{array}$ & $\begin{array}{l}\text { It's lucky that he was a good } \\
\text { cook. }\end{array}$ & $\sqrt{ }$ & & & $\mathbf{3}$ \\
\hline \hline
\end{tabular}

Based on the Larson's criteria of the naturalness of translation, the naturalness translation is written in ordinary language, common grammar, and using the proper idioms and words. Besides, a natural translation is also should have an equivalent meaning between the TL and SL.

Regarding to those criteria, it can be concluded that the table 4.1 is considered to fall into unnatural category. The mistake that was made by the translator can be seen from the translation of the TL which is not equivalent with the SL. In translating the story, the translator did not translate all the SL into the TL. So, it makes the meaning between the SL and $\mathrm{TL}$ is different and sounds unnatural.

Besides, the similar explanation comes from the NS 1 and NS 2. According to them, the sentence no.52 is in unnatural category. They explained that the meaning between the original sentence and target sentence is not closest. So, it makes that sentence sounds awkward and unnatural when it is read. In this case, the translator should translate the words lelaki yang berkumis tebal into English in order to make the SL and TL has an equivalent meaning. 


\subsection{Less natural Level}

Less natural data might be caused by the ungrammatical structures on the TL. Besides, less natural level is also might be caused by the several words which were not appropriate to be used to translate the SL. In this level, the data must cover 2.0-2.5 for the mean score. The result of the checklist analysis shows that the data which belonged to this level are $3(2.29 \%)$. The example of the less natural data can be seen on the Table 4.2.

Table 4.2. The short story entitled "Drupadi"

\begin{tabular}{|c|l|l|l|l|l|c|}
\hline No & $\begin{array}{l}\text { Source Language } \\
\text { (Indonesian Version) }\end{array}$ & $\begin{array}{l}\text { Target Language } \\
\text { (English Version) }\end{array}$ & $\mathbf{1}$ & $\mathbf{2}$ & $\mathbf{3}$ & $\mathbf{4}$ \\
\hline 119 & $\begin{array}{l}\text { Cuma sekarang aku jadi } \\
\text { tahu, itulah soal } \\
\text { sebenarnya mengapa ibu } \\
\text { sangat membenci diriku. }\end{array}$ & $\begin{array}{l}\text { But know I finally } \\
\text { understood that was what } \\
\text { making mother hate me so } \\
\text { much. }\end{array}$ & & $\sqrt{ }$ & \\
\hline \hline
\end{tabular}

Based on the Larson's criteria of the naturalness of translation, less natural category is a translation which has the correct meaning but there are some words which are not appropriate to be used and also there is ungrammatical structure that is done by the translator.

Regarding to the Larson's criteria, the sentence on the Table 4.2 was considered to fall into less natural category. The meaning of the TL was already closest with the SL, but there were several mistakes that are made by the translator. The first mistake was translator did not use the appropriate word in translating the SL into the TL. The translator translated the word sekarang into know, whereas the word know means understand of somethingand sekarang refers to the time.

The mistake that was made by the translator made the sentence on the Table 4.2 sounded unnatural. The meaning of the sentence between the SL and the TL was different. In this case, the translator should use now to translate the word sekarang. The word now has the same meaning with the word sekarang, now refers to the present time or the activity that carried on that time. Therefore, the appropriate word that is used to translate sekarang is now.

The second mistake was the use of "that" on the sentence "that was what making mother hate me so much". The use of "that" on that sentence was not appropriate and made that sentence sounded strength and awkward. The translator should delete the word "that" in order to make that sentence sounds natural.

The third mistake was the error structure on the sentence "that was what making mother hate me so much". The translator must change the words "what was" into "what was". It was because the main point of the original story was the writer could understand the cause of the problem that was faced by Drupadi. Therefore, the appropriate structure of the words "was what" was "what was".

Based on the analysis, it could be concluded that the correct sentence on 
the sentence no.119 is "But now I finally understood what was making mother hate me so much".

\subsection{Natural Level}

Natural data might be caused by there were several words which were not appropriate used by the translator in translating short story entitled "Drupadi" from Indonesian into English. In this level, the data must cover 3.0-3.5 for the mean score. The result of the checklist analysis shows that the data which belonged to this level were $18(13.74 \%)$. The example of the natural data can be seen on the Table 4.3.

Table 4.3. The Short Story Entitled "Drupadi"

\begin{tabular}{|c|l|l|l|c|c|c|}
\hline No & $\begin{array}{l}\text { Source Language } \\
\text { (Indonesian Version) }\end{array}$ & $\begin{array}{l}\text { Target Language } \\
\text { (English Version) }\end{array}$ & \multicolumn{3}{|c|}{ Score } \\
\hline 2 & $\begin{array}{l}\text { Anehnya, pada setiap } \\
\text { kelahiranku kembali aku } \\
\text { bertemu dengan kakek. }\end{array}$ & $\begin{array}{l}\text { And it's strange that } \\
\text { everything I'm born again I } \\
\text { always meet grandfather } \\
\text { again. }\end{array}$ & $\mathbf{1}$ & $\mathbf{3}$ & $\sqrt{ }$ & \\
\hline \hline
\end{tabular}

The sentence on the Table 4.3 was considered to fall into natural level. The structure of the sentence was structured and the meaning of the sentence between TL and SL was closest. However, there were several mistakes that were made by the translator. It could be seen from the use of word "everything" and "again". In translating the word "setiap", the translator translated it into "everything". In which, "setiap" refers to the time and the word "everything" refers to all things. Therefore, the translation between the TL was not equivalent with the SL. The appropriate word that could be used to translate the word "setiap" is "every time.

Another mistake that was made by the translator was the use of the word "again". The translator used the word "again"at the end of the sentence in order to translate the sentence aku bertemu dengan kakek. The use of the word "again" at the end of the sentence was not appropriate and it made that sentence sounded unnatural. The point of the original sentence was whenever Reytina born, she always meets with the same grandfather. Therefore, the word "again" on the sentence I'm born again I always meet grandfather again should be deleted. It is because the word always is already refers to again, so the use of the word "again" at the end of the sentence is not needed.

The similar explanation also comes from the both of native speakers. They stated that the sentence no. 2 is considered into "natural" level. They explained that there are several words which are not appropriate to be used by the translator, such as the used of word everything. The translator should change the word everything to every time, it is because setiap refers to the time and everything refers to all things. Besides, the translator also should delete the word again on the sentence I'm born again I always meet grandfather again. It is because the word always is already refers to again, so if the translator used the word again at the end of the sentence it will makes that sentence sounds unnatural. 


\subsection{Highly Natural Level}

Highly natural data might be caused by the structure of the sentence was structured, the meaning between TL and SL were equivalent and the sound of the sentence was natural. In this level, the data must cover 4.0 for the score. The result of the checklist analysis shows that the data which belonged to this level are 110 (83.97\%). The example of the highly natural data can be seen on the Table 4.4.

Table 4.4 The short story entitled "Drupadi"

\begin{tabular}{|c|l|l|l|l|c|c|}
\hline No & $\begin{array}{l}\text { Source Language } \\
\text { (Indonesian Version) }\end{array}$ & $\begin{array}{l}\text { Target Language } \\
\text { (English Version) }\end{array}$ & \multicolumn{3}{|c|}{ Score } \\
\hline 13 & $\begin{array}{l}\text { "Tergantung pada semua } \\
\text { karmamu, perbuatanmu." }\end{array}$ & $\begin{array}{l}\text { "It depends on your karma, } \\
\text { on everything you've done } \\
\text { in the past". }\end{array}$ & $\mathbf{3}$ & $\mathbf{3}$ & & $\sqrt{ }$ \\
\hline \hline
\end{tabular}

Based on the Larson's criteria of the naturalness of translation, the naturalness translation is written in ordinary language, common grammar, and using the proper idioms and words. Besides, a natural translation is also should have an equivalent meaning between the TL and SL.

Regarding to those criteria, the sentence on the table 4.4 was considered to fall into highly natural level. The grammar, structure, and collocation that were used by the translator to translate that sentence were appropriate. Besides, the message of the SL was delivered clearly into the $T L$, so it made that sentence did not sound awkward and strength.

In the other hands, the similar explanation comes from NS 1 and NS 2 .
According to them, the meaning between $T L$ and $S L$ on the sentence no.13 is closest and also sounds natural when it is read. Based on those reason, they concluded that the sentence no.13 is considered into "highly natural" category.

\section{The percentage of the naturalness of translation in tranmslating a short story entitled "Drupadi"}

The total of the sentences in the checklists were 131 sentences. In this study, the researcher classified the story sentence by sentence. The technique of the classifying was based on its translation. The result of the checklist form both of native speakers can be seen on the Table 4.5.

Table 4.5. The result both of checklists

\begin{tabular}{|c|l|l|}
\hline $\begin{array}{c}\text { Name of the native } \\
\text { speaker }\end{array}$ & \multicolumn{1}{|c|}{ Description } & Percentage (\%) \\
\hline \multirow{2}{*}{ NS 1 } & Highly natural & $83.97 \%$ \\
\cline { 2 - 3 } & Natural & $14.51 \%$ \\
\hline \hline
\end{tabular}




\begin{tabular}{|l|l|l|}
\hline \multirow{4}{*}{ NS 2 } & Less natural & $1.52 \%$ \\
\cline { 2 - 3 } & Unnatural & $0 \%$ \\
\hline \multirow{3}{*}{} & Highly natural & $67.17 \%$ \\
\cline { 2 - 3 } & Natural & $28.25 \%$ \\
\cline { 2 - 3 } & Less natural & $2.29 \%$ \\
\cline { 2 - 3 } & Unnatural & $2.29 \%$ \\
\hline \hline
\end{tabular}

According to NS 1, the short story entitled "Drupadi" is a great story and there are several moral values that contain in that story. However, there are lots of grammar mistake to be fixed. There are some English directly translated from Indonesian, which the reader should find different way to express the story.

The similar opinion comes from NS 2 , she stated that the short story entitled "Drupadi" is a good story and there are some of moral values that can be learned by the readers, such as karma, responsibility, and patience. However, there are lots of words which do not seem right and it not suitable with each other. There are some words are too exaggerated and difficult to get the right meaning. Besides, lots of sentences do not seem to use the correct word to express the meaning of its story, which in result no collaboration within the words and not well structured.

From both of the checklists, the most "unnatural" level comes from NS 2. It is because, according to NS 2 there are several grammar mistakes, mechanics error (spelling, punctuation, and repetition), and some inappropriate words that is used by the translator in translating the short story. There are three sentences which are considered into unnatural category based on NS 2, it can be seen on the Table 4.6.

Table 4.6. The short Story Entitled "Drupadi"

\begin{tabular}{|c|l|l|l|c|c|c|}
\hline No & $\begin{array}{l}\text { Source Language } \\
\text { (Indonesian Version) }\end{array}$ & $\begin{array}{l}\text { Target Language } \\
\text { (English Version) }\end{array}$ & \multicolumn{3}{|c|}{ Score } \\
\cline { 2 - 6 } & $\begin{array}{l}\text { Gambar- } \\
\text { gambarmenghablur dan } \\
\text { menghilang. }\end{array}$ & $\begin{array}{l}\text { And with that the picture } \\
\text { seemed to crystallize and } \\
\text { then fade away. }\end{array}$ & $\sqrt{ }$ & & $\mathbf{3}$ & $\mathbf{4}$ \\
\hline \hline
\end{tabular}

According to NS 2, the sentence on the table 4.6 was unnatural. In translating that sentence, the translator used inappropriate word and awkward language, so it made the meaning from TL quite different with the $S L$ and sounded unnatural. In order to make that sentence sounded natural and has an equivalent meaning with the SL, the translator must change the word "with that the picture seemed to crystallize" into "the pictures crystallize". It was because the word "with that the picture seemed to crystallize" was not appropriate to translate the word "gambar-gambar menghablur". Based on NS 2, that sentence sounded awkward 
and unnatural. Therefore, the appropriate word that was used to change that word is "the pictures crystallize."

Besides, the result of the checklists also shows that there are the several different opinions between NS 1 (native speaker 1) and NS 2 (native speaker 2). Based on the result, there are several sentences which have different score.

Table 4.9. The short Story Entitled "Drupadi"

\begin{tabular}{|c|l|l|l|c|c|}
\hline No & $\begin{array}{l}\text { Source Language } \\
\text { (Indonesian Version) }\end{array}$ & $\begin{array}{l}\text { Target Language } \\
\text { (English Version) }\end{array}$ & \multicolumn{3}{|c|}{ Score } \\
\hline 1 & $\begin{array}{l}\text { Aku ingat, inilah takdirku } \\
\text { yang keseratus untuk } \\
\text { menjalani hidup didunia } \\
\text { sebagai manusia. }\end{array}$ & $\begin{array}{l}\text { I remember now that is the } \\
\text { hundredth time l've been } \\
\text { born to live in this world. }\end{array}$ & $\mathbf{3}$ & $\mathbf{4}$ & \\
\hline \hline
\end{tabular}

According to NS 1, the sentence on the table 4.9 is already correct and natural. The NS 1 gave score 4 for the sentence on the table 4.9. Meanwhile, based on NS 2, the sentence on the table 4.8was quite unnatural and she gave score 3 for that sentence. The NS 2 stated that in translating the $\mathrm{TL}$, the translator should delete the sentence now. NS 2 explained that the sentence "I remember" already referred to Reytina's memory which she remembers all things that she has done. Therefore, the word "now" is not needed on that sentence.

According to Larson's criteria of the naturalness of translation, a highly natural category is should has an equivalent meaning between the TL and SL. Besides, a highly natural translation is also should make senses when it is read by the reader.

Regarding to the Larson's criteria, it can be concluded that the sentence no. 1 is considered into natural category. It can be seen from there is a word which is inappropriate to be used to translate that sentence. So, it makes the meaning of the $T L$ is quite different with the $S L$ and it sounds quite unnatural when it is read.

\section{CONCLUSION}

This study was conducted for the purpose of analyzing the naturalness of translation in translating short story entitled "Drupadi" from Indonesian into English and describing the percentage of the naturalness of translation in translating short story entitled "Drupadi" from Indonesia into English.

The total of the data in this study was 131 sentences. In this study, the researcher uses Larson's theory as the reference of the study in order to analyze the naturalness of translation in short story entitled "Drupadi" from Indonesian into English. The theory that is used by the researcher is the criteria of the naturalness of translation.

The result of this study showed that the short story entitled "Drupadi" which has been translated by Tom Hunter from Indonesian into English is in "highly natural" level with the percentage $83.97 \%$ Therefore, the short story entitled "Drupadi" can be used as teaching material in Senior High School, especially for ten grade students. However, before it is used as the learning material, that short 
story must be revised, it is because there are several sentences which are ungrammatical structures, mechanics error (spelling, punctuation, and repetition), and using inappropriate words in translating the target language (TL).

\section{REFERENCES}

Akhiroh, N. S. (2013). The Influence of Translation Technique on The Quality of The Translation of International News in Seputar Indonesia Daily.Journal of Language and Literature, 7(2).

Astalin, D. P. K. (2013). Qualitative Research Designs: A Conceptual Framework. International Journal of Social Science \& Interdisciplinary Research, 2(1).

Baker, M. (1992). In Other Words: $A$ CourseBooks on Translation. London: Routledge.

Barnwell, K. (1980). Introduction to Semantics and Translation. Horsley Green: Summer Institute of Linguistics.

Bell, R. T. (1991). Translation and Translating: Theory and Practice. London: Longman.

Colibaba, S. (2010). The Nature of Short Story: Attempts at Definition. Synergy, 6.

Denzin, N. (2010). An Introduction to Triangulation: UNAIDS Monitoring and Evaluation Fundamentals.

Fadaee, E. (2011). Translation Naturalness in Literary Works: English to Persian. International Journal of English and Literature., 2(9), 200-205. doi: 10.5897/IJEL11.089
Farahani, A. K., \& Ghasemi, M. (2012). The Naturalness in Translation of Idioms and Proverbs: The Case of a Persian Translation of Pinocchio. Journal of Language and Translation, 3(1), 17-22.

Fraenkle, J. R., \& Wallen, N. G. (1993). How to Design and Evaluate Research in Education (Second Edition ed.): Mc. Graw- Hill International Edition.

Gutt, E. A. (1999). Translation and Relevance : Cognition and Context. Oxford: Basil Blackwell Publication.

Hatim, B., \& Munday, J. (2004). Translation, An Advanceed Resource Book. London: Routledge.

Inés, P. R. (2014). Using Corpora for Awareness-Raising Purposes in Translation, Especially into A Foreign Language (SpanishEnglish). Perspectives: Studies in Translatology, 22(2). doi: 10.1080/0907676X.2012.685239

Larson, M. L. (1998). Meaning-Based Translation: A Guide to Cross Language Equivalence (Second Edition ed.). New York: University Press of America, Inc.

McMillan, J. H., \& Schumacher, S. (1993). Research in Education: $A$ conceptual Understanding. New York: HaprerCollins.

Miles, M. B., \& Huberman, A. M. (1994). Qualitative Data Analysis: An Expanded Sourcebook (R. Holland Ed. 2nd ed.). Newbury Park: Sage Publications.

Motallebzadeh, K., \& Tousi, S. (2011). Employing Compensation Strategy in Translation of Idioms: A Case Study of the Translation of MarkTwain's Adventures of 
Huckleberry Finn in Persian. International Journal of Linguistics, 3(1).

Mufti, A. R. A. (2014). An Analysis of Translation Procedures In Translating Figurative Words and Cultural Expressions In A Narrative Story Entitled "The Wizard of Oz" By Brown Watson. (Unpublished), Pendidikan Indonesia University.

Mustonen, S. (2010). Translating Idiom: $A$ case study on Donna Tartt's The Secret History and its Finnish translation. (S2), University of Jyväskylä.

Nababan, M. R. (2003). Teori Menerjemahkan Bahasa Inggris. Yogyakarta: Pustaka Pelajar.

Newmark, P. (1988). A Text Book of Translation London: Prentice $\mathrm{HaH}$ International vUIO Ltd.

Purwadi, Suwandi, S., Budiyono, \& Slamet, S. Y. (2013). The Effect of the Contextual, the ProblemBased, and the Group Investigation Learning Models on the Short Story Appreciation Ability Viewed from the Verbal Linguistic Intelligences. Journal of Education and Practice, 4(12), 90-102.

Rahimi, R. (2004). Alpha Beta and Gamma Features in Translation: Toward The Objectivity of Testing Translation. Translation Studies, 2(5).

Reynier, C. (2003). The short story according to Woolf. Journal of the Short Story in English 55-67.

Rosita, N., Isyam, A., \& Ardi, H. (2013). The English Students' Techniques in Translating Indonesian Beverage Terms into English. Journal of English Language Teaching, 1(2), 307-318.
Sari, W. P., Refnaldi, \& Ardi, H. (2013). Translation Techniques and Translation Accuracy of English Translated Text of Tourism Brochure in Tanah Datar Regency. English Language and Literature E-Journal.

Shuttleworth, M., \& Cowie, M. (2014). Dictionary of Translation Studies. NewYork: Routledge.

Sukirmiyadi, Tarjana, S. S., \& Nababan, M. R. (2014). A Study on the Quality of Abstract Translation of Dissertation from Indonesian into English. International Journal of Linguistics., 6(2). doi: 10.5296/ijl.v6i2.5552

Yarahmadzehi, N., Beikian, A., \& Nadri, F. (2013). A Study of Persian Translations of English Phrasal Verbs in Harry Potter and the Order of the Phoenix. International Journal of English Linguistics, 3(1). doi: 10.5539/ijel.v3n1p60 